\title{
Thermoelectric Properties of Perovskite-Type Related Compounds Ca-Mn-O Systems
}

\author{
H. Kawakami, H. Noda, M. Sugimoto, T. Takayama and H. Yamamura, \\ Department of Material and Life Chemistry, Faculty of Engineering, Kanagawa University \\ 3-37-1 Rokkakubashi, Kanagawa-ku, Yokohama, 221-8686, Japan \\ Fax: 81-045-413-9770, e-mail: hiroshikawakami627@yahoo.co.jp
}

\begin{abstract}
Tetragonal layered perovskite-type oxide systems $\mathrm{Ca}_{2.73-\mathrm{m}} \mathrm{Nd}_{\mathrm{m}} \mathrm{Mn}_{2} \mathrm{O}_{7-\delta} \quad(0 \leqq \mathrm{~m} \leqq 0.18)$ and orthorhombic perovskite-type oxide systems having A-site vacancy, $\mathrm{Ca}_{1-\mathrm{n}} \square_{\mathrm{n}} \mathrm{MnO}_{3}$ and $\mathrm{Ca}_{0.9-\mathrm{n}} \mathrm{Nd}_{0.1} \square$ ${ }_{n} \mathrm{MnO}_{3}$, were synthesized by a standard ceramic technique. The thermoelectric properties such as Seebeck coefficient (S), thermal conductivity $(\kappa)$ and electrical conductivity $(\sigma)$ were investigated as functions of temperature and composition. The effect of insertion of rock salt layer or A-site vacancy to the perovskite-type structure on the thermoelectric properties, were clarified.
\end{abstract}

Key words: thermoelectric, layered perovskites, thermal conductivity, oxide semiconductor, electrical conductivity.

\section{INTRODUCTION}

Thermoelectric power generation ${ }^{1)}$ which is an useful energy supply system occurs by the difference in temperature. High temperature thermoelectric materials need high thermal and chemical stability for long time use at high temperatures in air. Therefore, the metal oxides which have both high thermal and chemical stability are one of suitable candidate for high thermoelectric materials.

The performance of thermoelectric materials is given by the figure of merit $Z$ as follows,

$$
\mathrm{Z}=\mathrm{S}^{2} \sigma / \kappa
$$

where $S, \sigma$ and $\kappa$ is the Seebeck coefficient, the electrical conductivity and the thermal conductivity, respectively. Otaki et al. ${ }^{23)}$ reported $Z=0.14 \times 10^{-3}$ $\mathrm{K}^{-1}(\mathrm{ZT}=0.16$ at $\mathrm{T}=1173 \mathrm{~K})$ for the polycrystalline sample of $\mathrm{CaMnO}_{3}$ which has a perovskite-type structure. Further decrease in the thermal conductivity is necessary for the enhancement of the figure of merit ${ }^{4}$. In this study, we paid attention to perovskite-type related compounds which have Ruddlesden-popper structure ${ }^{5)}$ with a general formula of $\mathrm{AO} \cdot \mathrm{n}(\mathrm{ABO})_{3}$, or which have the A-site vacancy in perovskite structure with a general formula of $\mathrm{A}_{1-\mathrm{x}} \mathrm{BO}_{3-\mathrm{x}}$. Ruddlesden-popper structure includes lock salt layers (We called it heat resistance layers (HRL)). In the present study, the thermoelectric properties of the systems, $\mathrm{Ca}_{1-\mathrm{m}} \mathrm{Nd}_{\mathrm{m}} \mathrm{MnO}_{3}$ (Fig.1(a)) $\mathrm{Ca}_{2.73-\mathrm{m}} \mathrm{Nd}_{\mathrm{m}} \mathrm{Mn}_{2} \mathrm{O}_{7-\delta}$ (Fig.1(b)), and $\mathrm{Ca}_{0.9-\mathrm{n}} \mathrm{Nd}_{0.1} \square$ ${ }_{n} \mathrm{MnO}_{3}$ (Fig.1(c)), were investigated.

\section{EXPERIMENTAL}

All samples systems were prepared by solid state reaction. The starting materials of $\mathrm{CaCO}_{3}(99.99 \%$, Kojundo chemical), $\mathrm{Nd}_{2} \mathrm{O}_{3}(99.99 \%$, Kojundo chemical $)$ and $\mathrm{MnO}_{2}$ (99.99\%, Kojundo chemical) were mixed for $24 \mathrm{~h}$ using ball mill. The mixed powders, which were sieved to under $53 \mu \mathrm{m}$, were pressed at $50 \mathrm{kgf} \mathrm{cm}^{-2}$ into a rectangular shape and then subjected to rubber pressing at $2000 \mathrm{kgf} \mathrm{cm}^{-2}$. These samples were sintered at $1573 \mathrm{~K}$ for $10 \mathrm{~h}$ and $1673 \mathrm{~K}$ for $10 \mathrm{~h}$ in air, respectively. The identification of the samples and the determination of lattice constant were performed by $\mathrm{X}$-ray diffractmetry using $\mathrm{Cu} \mathrm{K} \alpha$ radiation at room temperature.

The electrical conductivity of sintered sample was measured by the DC four-probe method at various constant temperatures in the temperature range from 873 to $1273 \mathrm{~K}$. The thermal conductivity of sintered sample was measured by the comparison method at $873 \mathrm{~K}$, and the Seebeck coefficient was also measured at the same temperature.

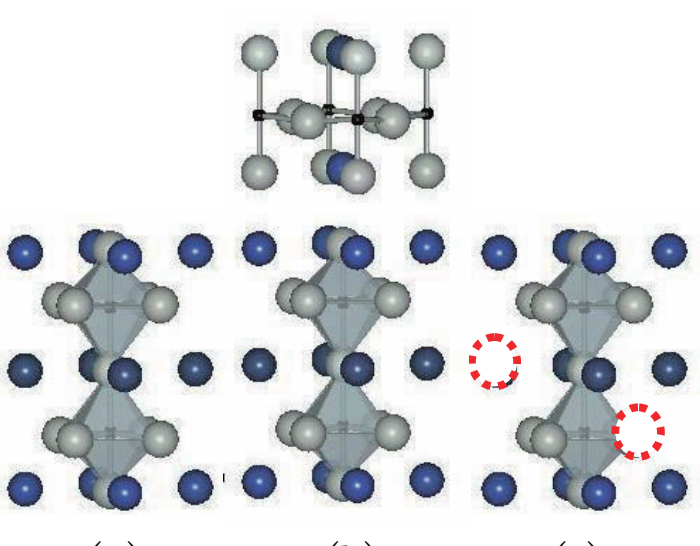

(a) (c)

Fig.1 Schematic representation of crystal structures of perovskite-type related compounds; perovskite-type structure of $\mathrm{Ca}_{1-\mathrm{m}} \mathrm{Nd}_{\mathrm{m}} \mathrm{MnO}_{3}(\mathrm{a})$, Ruddlessden-Popper structure $\mathrm{Ca}_{2.73-\mathrm{m}} \mathrm{Nd}_{\mathrm{m}} \mathrm{Mn}_{2} \mathrm{O}_{7-\delta}(\mathrm{b})$ and perovskite-type structure having lattice vacancies of $\mathrm{Ca}_{0.9-\mathrm{n}} \mathrm{Nd}_{0.1} \square$ ${ }_{\mathrm{n}} \mathrm{MnO}_{3-\mathrm{n}}(\mathrm{c})$, where $\because$ shows lattice vacancies. 


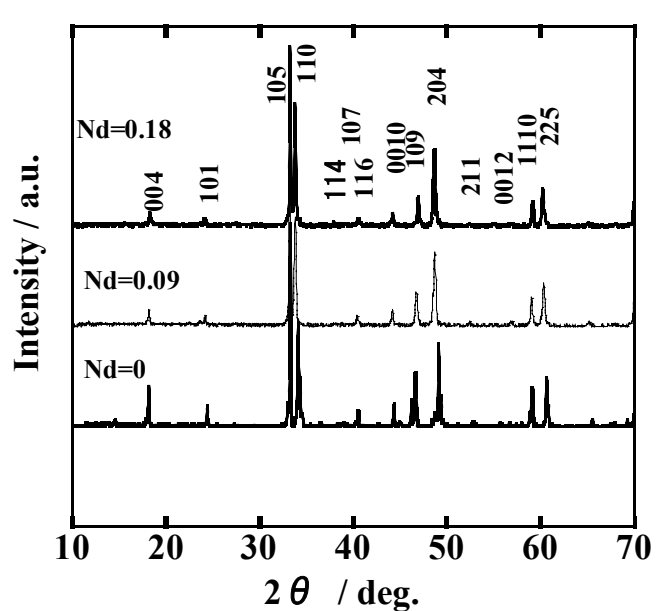

Fig.2 XRD patterns of $\mathrm{Ca}_{2.73-\mathrm{m}} \mathrm{Nd}_{\mathrm{m}} \mathrm{Mn}_{2} \mathrm{O}_{7-\delta}$.

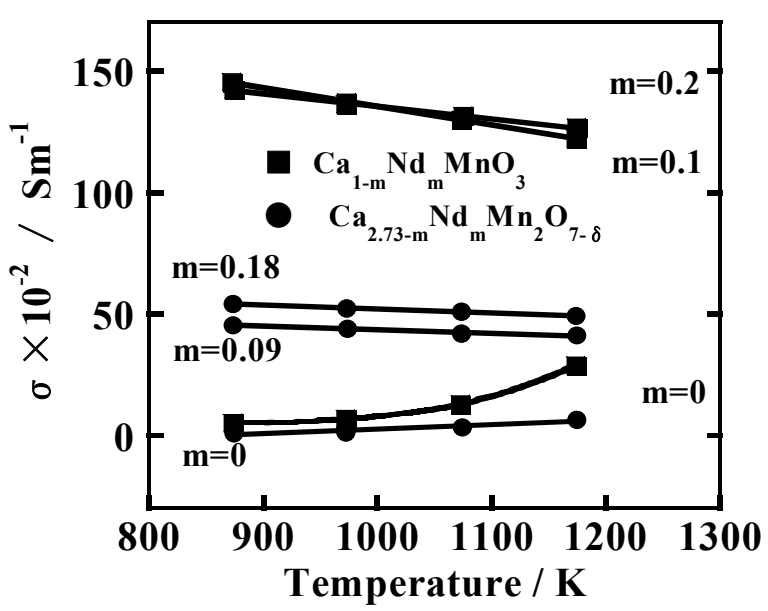

Fig.3 Electrical conductivity of $\mathrm{Ca}_{1-\mathrm{m}} \mathrm{Nd}_{\mathrm{m}} \mathrm{MnO}_{3}$ and $\mathrm{Ca}_{2.73-\mathrm{m}} \mathrm{Nd}_{\mathrm{m}} \mathrm{Mn}_{2} \mathrm{O}_{7-\delta}$.

\section{RESULT AND DISCUSSION}

3.1 Ruddlessden- Popper structure

The powder XRD patterns of $\mathrm{Ca}_{1-\mathrm{m}} \mathrm{Nd}_{\mathrm{m}} \mathrm{MnO}_{3}(0 \leqq$ $\mathrm{m} \leqq 0.2)$ and $\mathrm{Ca}_{2.73-\mathrm{m}} \mathrm{Nd}_{\mathrm{m}} \mathrm{Mn}_{2} \mathrm{O}_{7-\delta}(0 \leqq \mathrm{~m} \leqq 0.18)$ were completely indexed according to orthorhombic $\mathrm{CaMnO}_{3}$-type structure and tetragonal $\mathrm{Ca}_{3} \mathrm{Mn}_{2} \mathrm{O}_{7}$-type structure, respectively (Fig.2). Figure 3 shows the electrical conductivity of both $\mathrm{Ca}_{2.73-\mathrm{m}} \mathrm{Nd}_{\mathrm{m}} \mathrm{Mn}_{2} \mathrm{O}_{7-\delta}$ and $\mathrm{Ca}_{1-\mathrm{m}} \mathrm{Nd}_{\mathrm{m}} \mathrm{MnO}_{3}$ systems as a function of temperature. The electrical conductivities of both systems increased with increasing $\mathrm{m}$. The increase in the electrical conductivity may originate from the increase in carrier concentration due to the change of $\mathrm{Mn}^{4+}$ into $\mathrm{Mn}^{3+}$ by doping $\mathrm{Nd}^{3+}$ into $\mathrm{Ca}^{2+}$ site. In addition, the electrical conductivities of $\mathrm{Ca}_{2.73-\mathrm{m}} \mathrm{Nd}_{\mathrm{m}} \mathrm{Mn}_{2} \mathrm{O}_{7-\delta}$ were lower than that of $\mathrm{Ca}_{1-\mathrm{m}} \mathrm{Nd}_{\mathrm{m}} \mathrm{MnO}_{3}$, when they were compared for the composition with the same $\mathrm{m}$ value. This result suggests that the HRL of the rock salt structure may disturb electrical conduction. Seebeck coefficient measurements showed n-type semiconductor for the all samples. Figure 4 shows the relationship between the power factor $\left(\mathrm{S}^{2} \sigma\right)$ and the $\mathrm{Nd}$ content $(\mathrm{m})$. The power

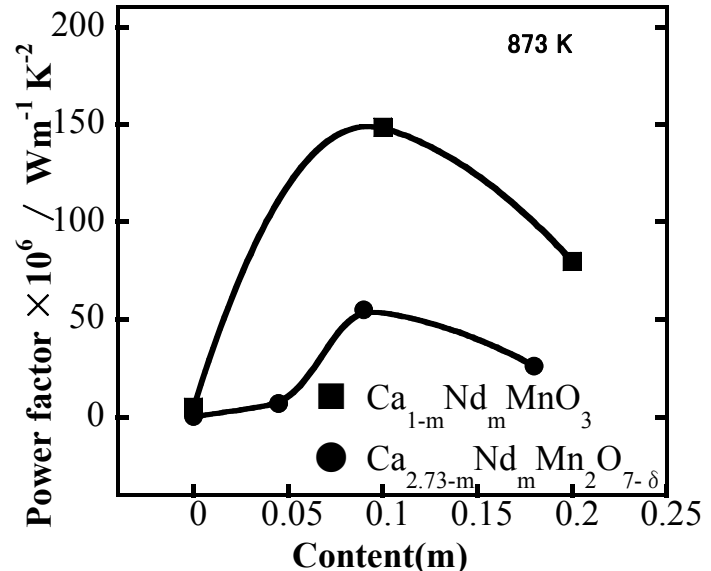

Fig.4 Power factor for $\mathrm{Ca}_{1-\mathrm{m}} \mathrm{Nd}_{\mathrm{m}} \mathrm{MnO}_{3}$ and $\mathrm{Ca}_{2.73-\mathrm{m}} \mathrm{Nd}_{\mathrm{m}} \mathrm{Mn}_{2} \mathrm{O}_{7-\delta}$ at $873 \mathrm{~K}$.

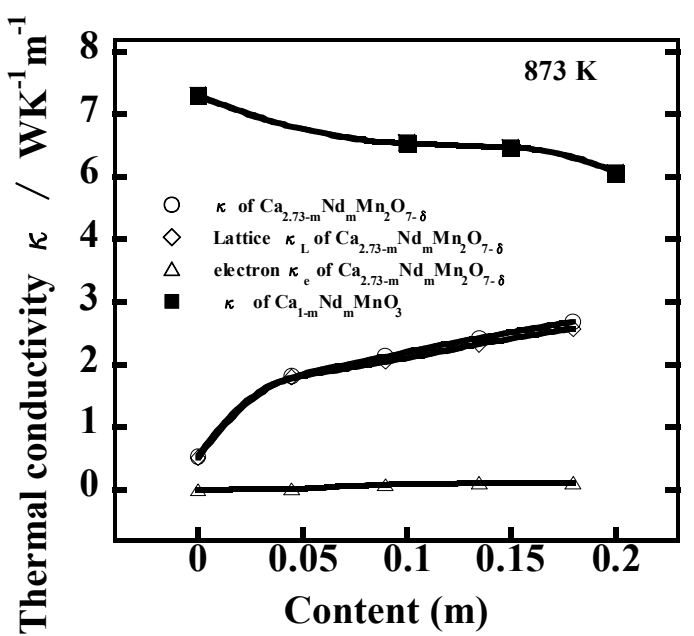

Fig.5 Thermal conductivity of $\mathrm{Ca}{ }_{1-\mathrm{m}} \mathrm{Nd}_{\mathrm{m}} \mathrm{MnO}_{3}$ and $\mathrm{Ca}_{2.73-\mathrm{m}} \mathrm{Nd}_{\mathrm{m}} \mathrm{Mn}_{2} \mathrm{O}_{7-\delta}$ as a fanction of $\mathrm{m}$.

factor of $\mathrm{Ca}_{2.73-\mathrm{m}} \mathrm{Nd}_{\mathrm{m}} \mathrm{Mn}_{2} \mathrm{O}_{7-\delta}$ was lower than that of $\mathrm{Ca}_{1-\mathrm{m}} \mathrm{Nd}_{\mathrm{m}} \mathrm{MnO}_{3}$. This origin may be due to the difference in the electrical conductivity and due to the smaller $\kappa$ value of $\mathrm{Ca}_{2.73-\mathrm{m}} \mathrm{Nd}_{\mathrm{m}} \mathrm{Mn}_{2} \mathrm{O}_{7-\delta}$ than that of $\mathrm{Ca}_{1-\mathrm{m}} \mathrm{Nd}_{\mathrm{m}} \mathrm{MnO}_{3}$ due to the effect of HRL. Figure 5 represents the thermal conductivity as a function of the $\mathrm{Nd}$ content. Here, the electronic thermal conductivity $\left(\kappa_{\mathrm{e}}\right)$ is given by the following equation:

$$
\kappa_{\mathrm{e}}=\mathrm{L} \sigma \mathrm{T},
$$

where L represents the Lorenz number $\left(2.44 \times 10^{-8} \mathrm{~W}\right.$ $\mathrm{S}^{-1} \mathrm{~K}^{-2}$ ). On the other hand, the lattice thermal conduc tivity $\left(\kappa_{\mathrm{L}}\right)$ can be given by the following equation:

$$
\kappa_{\mathrm{L}}=\kappa-\kappa_{\mathrm{e}} .
$$

The $\kappa$ value of the $\mathrm{Ca}_{1-\mathrm{m}} \mathrm{Nd}_{\mathrm{m}} \mathrm{MnO}_{3}$ system decreased with increasing $\mathrm{m}$, while that of $\mathrm{Ca}_{2.73-\mathrm{m}} \mathrm{Nd}_{\mathrm{m}} \mathrm{Mn}_{2} \mathrm{O}_{7-\delta}$ increased with increasing m. Fig. 5 shows that the $\kappa$ value of $\mathrm{Ca}_{2.73-\mathrm{m}} \mathrm{Nd}_{\mathrm{m}} \mathrm{Mn}_{2} \mathrm{O}_{7-\delta}$ increases with increase in the $\kappa_{\mathrm{L}}$ value. This result suggests that the increase in $\kappa_{\mathrm{L}}$ as well as $\kappa$ corresponds to the decrease in the effect of HRL. 


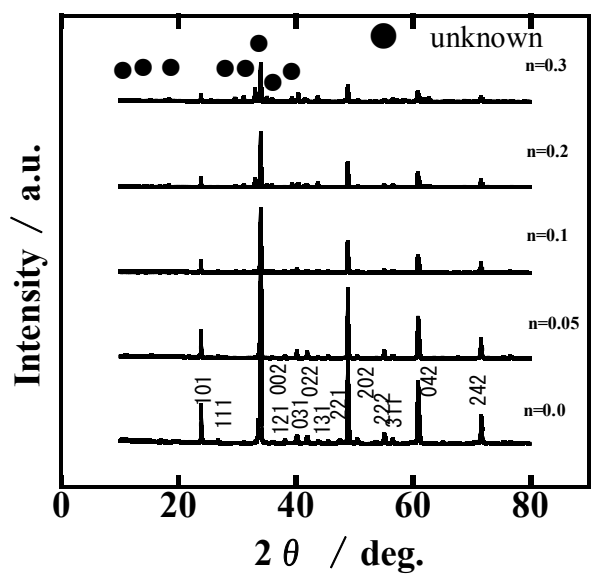

Fig.6 XRD patterns for $\mathrm{Ca}_{1-\mathrm{n}} \square_{\mathrm{n}} \mathrm{MnO}_{3-\mathrm{n}}$.

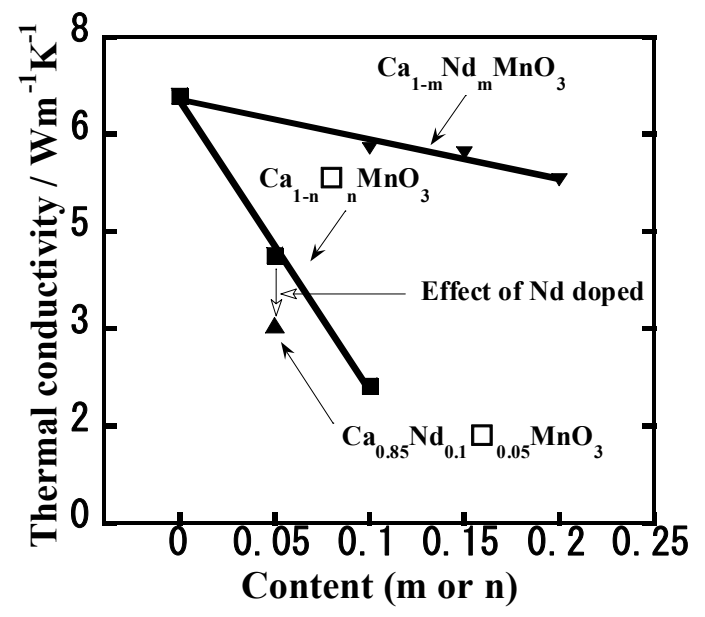

Fig.7 Thermal conductivity of of Ca-Mn-O system.

3.2 A-site vacancy inserted in perovskite structure

The powder XRD patterns of $\mathrm{Ca}_{1-\mathrm{n}} \square_{\mathrm{n}} \mathrm{MnO}_{3-\mathrm{n}}(0 \leqq \mathrm{n}$ $\leqq 0.1)$ and $\mathrm{Ca}_{0.9-\mathrm{n}} \mathrm{Nd}_{0.1} \square_{\mathrm{n}} \mathrm{MnO}_{3}(0 \leqq \mathrm{n} \leqq 0.1)$ were completely indexed according to the orthorhombic $\mathrm{CaMnO}_{3}$ - type structure. The XRD patterns of $\mathrm{Ca}_{1-n}$ $\square{ }_{\mathrm{n}} \mathrm{MnO}_{3-\mathrm{n}}(0.1<\mathrm{n} \leqq 0.3)$ should the mixed phases (Fig.6). Figure 7 shows thermal conductivities ( $\kappa)$ of $\mathrm{Ca}_{1-\mathrm{n}} \square{ }_{n} \mathrm{MnO}_{3-\mathrm{n}}$, $\mathrm{Ca}_{1-\mathrm{m}} \mathrm{Nd}_{\mathrm{m}} \mathrm{MnO}_{3}$ and $\mathrm{Ca}_{0.85} \mathrm{Nd}_{0.1} \square_{0.5} \mathrm{MnO}_{3}$ systems at $873 \mathrm{~K}$. The $\kappa$ value of $\mathrm{Ca}_{1-\mathrm{n}} \square{ }_{\mathrm{n}} \mathrm{MnO}_{3-\mathrm{n}}$ decreased with increasing the A-site vacancy. From this result, we suggested that the both of Asite vacancy and oxygen vacancy showed heat resistance points (HRP), and lowered the thermal conductivity. In addition, the $\mathrm{Nd}$-doped $\mathrm{Ca}_{1-n} \square$ ${ }_{n} \mathrm{MnO}_{3-\mathrm{n}}$ was further lowered the $\kappa$ value.For example, $\mathrm{Ca}_{0.85} \mathrm{Nd}_{0.1} \square 0.05 \mathrm{MnO}_{3}$ reduced the $\kappa$ value from $4.4 \mathrm{Wm}^{-1} \mathrm{~K}^{-1}$ to $3.3 \mathrm{Wm}^{-1} \mathrm{~K}^{-1}$. Figure 8 shows the electrical conductivity of the $\mathrm{Ca}_{0.9-\mathrm{n}} \mathrm{Nd}_{0.1} \square$ ${ }_{n} \mathrm{MnO}_{3}$ system as a function of tenperature. The electrical conductivities of this system increased with increasing $\mathrm{n}$ up to $\mathrm{n}=0.1$, and indicated the larger value than that of $\mathrm{Ca}_{1-\mathrm{m}} \mathrm{Nd}_{\mathrm{m}} \mathrm{MnO}_{3}$. Here, the carrier generation mechanism of both $\mathrm{Ca}_{1-\mathrm{m}} \mathrm{Nd}_{\mathrm{m}} \mathrm{MnO}_{3}$ (Eq.4) and $\mathrm{Ca}_{0.9-\mathrm{n}} \mathrm{Nd}_{0.1} \square_{\mathrm{n}} \mathrm{MnO}_{3}(0.05 \leqq \mathrm{n})$ (Eq.5) are given by the

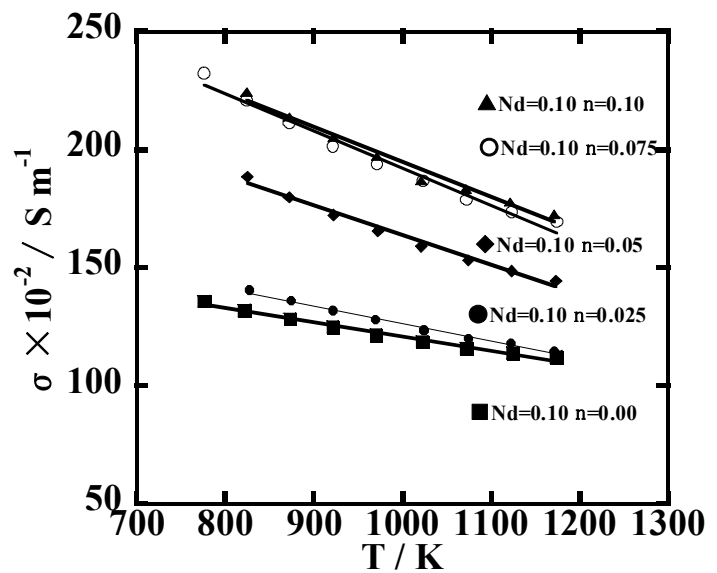

Fig.8 Electrical conductivty for $\mathrm{Ca}_{0.9-\mathrm{n}} \mathrm{Nd}_{0.1} \square_{\mathrm{n}} \mathrm{MnO}_{3}$.

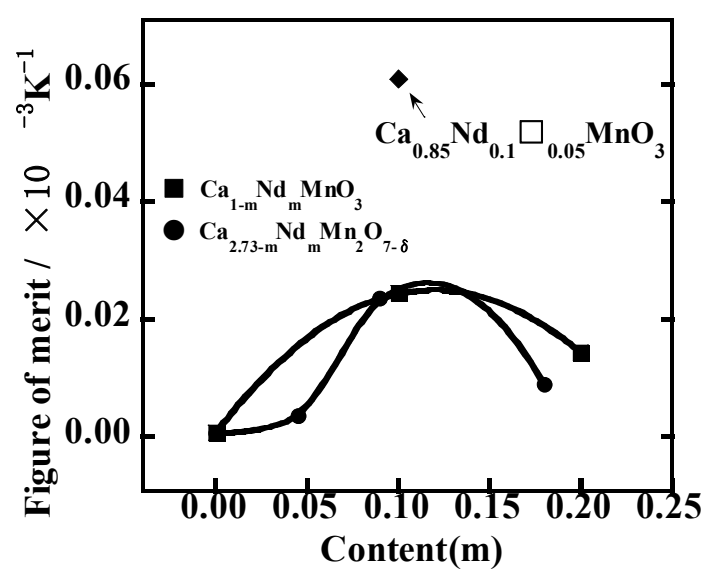

Fig.9 Figure of merit for Ca-Mn-O systems.

following equations, respectively.

$$
\begin{aligned}
& \mathrm{Nd}_{2} \mathrm{O}_{3}=2 \mathrm{Nd}_{\mathrm{Ca}} \cdot+2 \mathrm{e}^{\prime}+2 \mathrm{O}_{\mathrm{O}}{ }^{\times}+1 / 2 \mathrm{O}_{2}(\mathrm{~g}) \ldots \\
& \mathrm{O}_{\mathrm{O}}{ }^{\times} \rightarrow \mathrm{V}_{\mathrm{O}} \cdot \cdots+2 \mathrm{e}^{\prime}+1 / 2 \mathrm{O}_{2}(\mathrm{~g}) \ldots(5)
\end{aligned}
$$

The larger electrical conductivities of $\mathrm{Ca}_{0.9-\mathrm{n}} \mathrm{Nd}_{0.1} \square$ ${ }_{n} \mathrm{MnO}_{3}(0.05 \leqq \mathrm{n})$ than that of $\mathrm{Ca}_{1-\mathrm{m}} \mathrm{Nd}_{\mathrm{m}} \mathrm{MnO}_{3}$ may originate from the increase in the carrier concentration according to Eqs. (4) and (5). Although the electrical conductivity was increased by the insertion of A-site vacancy into the perovskite-type structure, Seebeck coefficient of $\mathrm{Ca}_{0.9-\mathrm{n}} \mathrm{Nd}_{0.1} \square_{\mathrm{n}} \mathrm{MnO}_{3}$ did not change so much at $873 \mathrm{~K}$. This reason is future problem.

\section{3-3 Figure of merit $Z$}

Figure 9 represents the figure of merit $(Z)$ as a function of the $\mathrm{Nd}$ content $(\mathrm{m})$. The $\mathrm{Z}$ values of $\mathrm{Ca}_{2.73-\mathrm{m}} \mathrm{Nd}_{\mathrm{m}} \mathrm{Mn}_{2} \mathrm{O}_{7-\delta}$ and $\mathrm{Ca}_{1-\mathrm{m}} \mathrm{Nd}_{\mathrm{m}} \mathrm{MnO}_{3}$ were similar level with each other. This reason may originate from that although the thermal conductivity of $\mathrm{Ca}_{2.73-\mathrm{m}} \mathrm{Nd}_{\mathrm{m}} \mathrm{Mn}_{2} \mathrm{O}_{7-\delta}$ was decreased by $\mathrm{HRL}$, the electrical conductivity of $\mathrm{Ca}_{2.73-\mathrm{m}} \mathrm{Nd}_{\mathrm{m}} \mathrm{Mn}_{2} \mathrm{O}_{7-\delta}$ also decrease by HRL. We considered that the insertion of HRL could not improve the figure of merit. On the other hand, the insertion of A-site vacancy into 
perovskite-type structure could improve the figure of merit due to the decrease in thermal conductivity and the increase in electrical conductivity. In addition, we obtain the maximum figure of merit $\mathrm{Z}$ of $0.06 \times 10^{-3} \mathrm{~K}^{-1}$ at $873 \mathrm{~K}$. Thus, the insertion of A-site vacancy into the perovskite-type structure could be the new method for enhancement of thermoelectric performance.

\section{CONCLUSION}

Tetragonal layered perovskite-type oxide systems $\mathrm{Ca}_{2.73-\mathrm{m}} \mathrm{Nd}_{\mathrm{m}} \mathrm{Mn}_{2} \mathrm{O}_{7-\delta} \quad(0 \leqq \mathrm{~m} \leqq 0.18)$ and the orthorhombic perovskite-type oxide systems having Asite vacancy, $\mathrm{Ca}_{1-\mathrm{n}} \square_{\mathrm{n}} \mathrm{MnO}_{3-\mathrm{x}}$ and $\mathrm{Ca}_{0.9-\mathrm{n}} \mathrm{Nd}_{0.1} \square_{\mathrm{n}} \mathrm{MnO}_{3}$ were synthesized by a standard ceramic technique. All samples showed a n-type semiconductor from the measurement of Seebeck coefficient (S), the thermal conductivity $(\kappa)$ and the electrical conductivity $(\sigma)$. The insertion of HRL or HRP to the perovskite-type structure lowered the thermal conductivity. The electrical conductivity decreased by the insertion of HRL. However, the insertion of HRP improved the thermoelectric performance. $\mathrm{Ca}_{0.85} \mathrm{Nd}_{0.1} \square_{0.05} \mathrm{MnO}_{3}$ showed the maximum figure of merit of $0.06 \times 10^{-3} \mathrm{~K}^{-1}$ at $873 \mathrm{~K}$ among the ( $\mathrm{Ca}, \mathrm{Nd}$ ) $-\mathrm{Mn}-\mathrm{O}$ systems.

\section{ACKNOWLEDGMENT}

This study was supported by Scientific Frontier Research Project of the Ministry of Education, Sports, Science, and Technology, Japan.

\section{REFERENCES}

1) R. Funahashi, M. Mikami, T.Mihara, J.APPLIED PHYSICS, 99, 066117(2006)

2) M. Ohtaki, T. Tokunaga, K. Eguchi, H. Arai, 16th Inter. Confe. Thermo., 224 (1997)

3) D. Flahaut, T.Mihara, R. Funahashi, J.APPLIED PHYSICS, 100, 084911(2006)

4) G. A. Slack, "CRC Handbook of Thermoelectrics" (1995)

5) S. N. Ruddlesden, P. Popper, Acta Crystal- logr. 11, $54(1958)$

(Received January 25, 2009; Accepted April 3, 2009) 